\section{Journal of Global \\ Management Sciences}

Vol. 4, $\mathrm{N}^{\circ} 1,2021$

\title{
Use's perception of the social networks in young people at the Ica city, 2020 \\ [Percepción sobre el uso de las redes sociales en jóvenes de la ciudad de Ica, 2020]
}

\author{
Alejandro Alfredo Quispe Mayuri (iD*, Leonidas Alejandro Maldonado Bendezú \\ *ika17@hotmail.com
}

Received: 4 May 2021; Accepted: 8 June 2021; Published: 24 June 2021

\begin{abstract}
Resumen
La investigación se orientó al desarrollo de percepción del uso de las redes sociales en jóvenes de la ciudad de Ica. El estudio buscó conocer los hábitos y costumbres de los investigados, sobre el uso de redes y el rol que juegan los dispositivos que producen, reciben, procesan, almacenan y transmiten la información sin condiciones de distancia, y en tiempo real. La investigación fue cualitativa a la par de descriptiva. La población estuvo constituida por 59247 jóvenes mayores de 20 años a 30 años y la muestra 384 jóvenes (120 fueron damas y 264 varones). Se utilizó la técnica de la encuesta y el instrumento fue el cuestionario. Se concluyó que los jóvenes, por sus características personales y los conflictos que les está tocando vivir, requieren de un mundo personal y social donde la familia, sus amigos y las personas queridas compartan sus vidas. Las redes sociales, se constituyen como una alternativa para lograr satisfacer estas necesidades, lo que está generando día a día un incremento de su adicción por ser partícipes en las diversas alternativas que estos entornos ofrecen. Los resultados fueron: $43.49 \%$ manifestó que usa frecuentemente el internet, un $25,7 \%$ expresó que es Facebook la red social de su preferencia, otro 54.17 manifestó que es indispensable el uso de la red social de su preferencia, un $34.9 \%$ dijo que actividades importantes por estar conectado a una red social, además de que un 40.36 estableció que lo que más le atrae es conversar con las amistades.
\end{abstract}

Palabras clave: Internet, Redes sociales, Jóvenes

\begin{abstract}
The research was oriented to the development of perception of the use of social networks in young people of the city of Ica. The study sought to know the habits and customs of those investigated, about the use of networks and the role played by the devices that produce, receive, process, store and transmit information without distance conditions, and in real time. The research was qualitative as well as descriptive. The population consisted of 59,247 young people aged 20 to 30 years and the sample 384 young people (120 were women and 264 men). The survey technique was used and the instrument was the questionnaire. It was concluded that young people, due to their personal characteristics and the conflicts that they are experiencing, require a personal and social world where family, friends and loved ones share their lives. Social networks are constituted as an alternative to satisfy these needs, which is generating an increase in their addiction day by day because they are participants in the various alternatives that these environments offer. The results were: $43.49 \%$ said that they frequently use the internet, $25.7 \%$ said that Facebook is the social network of their preference, another 54.17 said that it is essential to use the social network of their preference, $34.9 \%$ said that important activities for being connected to a social network, in addition to a 40.36 established that what most attracts them is talking with friends.
\end{abstract}

Keywords: Internet, Social networks, Young people. 
Vol. 4, $\mathrm{N}^{\circ}$ 1, 2021

\section{GMS \\ Journal of Global Management Sciences}

Copyright @ 2021, CINCADER.

ISSN 2663-0753

DOI: https://doi.org/10.32829/gmsj.v4i1.128

\begin{abstract}
1. Introduction
The purpose of the present study was to develop a vision of what the use of social networks means in the young people of the city of Ica, and with this to know their habits and customs, forms, times, and networks preferred by young people. Nowadays, social networks are considered as new forms of socialization, and that from them a source of interaction between people can be generated. The Internet is known to give people who are isolated for various reasons the possibility to communicate or belong to social groups. This constitutes one of the most relevant characteristics of this network and it is appreciated that a certain audience in their communities are people with some kind of isolation. This characteristic is not a generalization, since commonly notorious individuals also find the possibility of being even more so on the Internet, in this way social communities emerge in cyberspace. It is known that the interactions, agreements or motivations of groups with residences in cyberspace, determine actions in the physical world. In this regard, communities rarely exist exclusively in cyberspace. It is important to investigate the way in which social groups created in cyberspace expand in the real world and viceversa". In relation to the constitution of groups in cyberspace, according to Zea and Atuesta (2008: p39), they tell us that; "Although communities can emerge from and exist within groups united through computer networks, the technical electronic link of people is not enough to create them. The community includes more than the simple exchange of information: it is characterized, generally, by social contracts, reciprocity and economy".
\end{abstract}

In recent years, the use of the Internet has been increasing (Blázquez et al., 2018), occupying an important space in people's daily lives, due to the fact that it is currently used in multiple contexts with different purposes (Rodríguez \& Sandoval, 2017). In fact, young people are the most active users (García, 2011). Various studies indicate that the people who most use this resource are between 12 and 34 years of age (Arredondo, 2007). They browse the Internet daily, obtain information, communicate by mail, make friends on social networks and on many occasions they are the producers of the content (Gómez, Roses \& Farias, 2012), and those who are discovering how to use the applications that, day by day, are born on the web.

It is important to consider that people live with family, educational institution, friends, and the media. They are called primary socializing agents who have a strong influence on possible actions. The above is related to the concept of the network society.

\title{
2. Materials and Methods
}

Research is qualitative to better meet the demands of the research problem it faces and it is established that it is a form of study to know who, where, when, how and why of the subject of study. A descriptive design is used to carry out an investigation, when the objective is: to describe the characteristics of certain groups, to calculate the proportion of people in a given population with certain characteristics, as well as to forecast (Namakforoosh, 2005). The population of young people over 20 years old up to 30 years old was taken into account for the present research, which, according to the INEI, establishes that the 2007 census shows an approximate of 59247 young people, from the city of Ica, being the resulting sample of 384 young people (120 were women and 264 men). The survey technique was used and the instrument was the questionnaire, which is based on a series of questions with the purpose of obtaining information from those consulted, considering for the study 9 questions that were applied to the sample under study. 
Vol. 4, $\mathrm{N}^{\circ}$ 1, 2021

\section{Results}

Table 1. Frequency of Internet use

\begin{tabular}{lcc}
\hline \multicolumn{1}{c}{ Alternatives } & Frequency & $\begin{array}{c}\text { Percentage } \\
(\%)\end{array}$ \\
\hline Infrequent & 82 & 21.35 \\
Regularly & 135 & 31.16 \\
Frequently & 167 & 43.49 \\
\hline Total & 384 & 100 \\
\hline
\end{tabular}

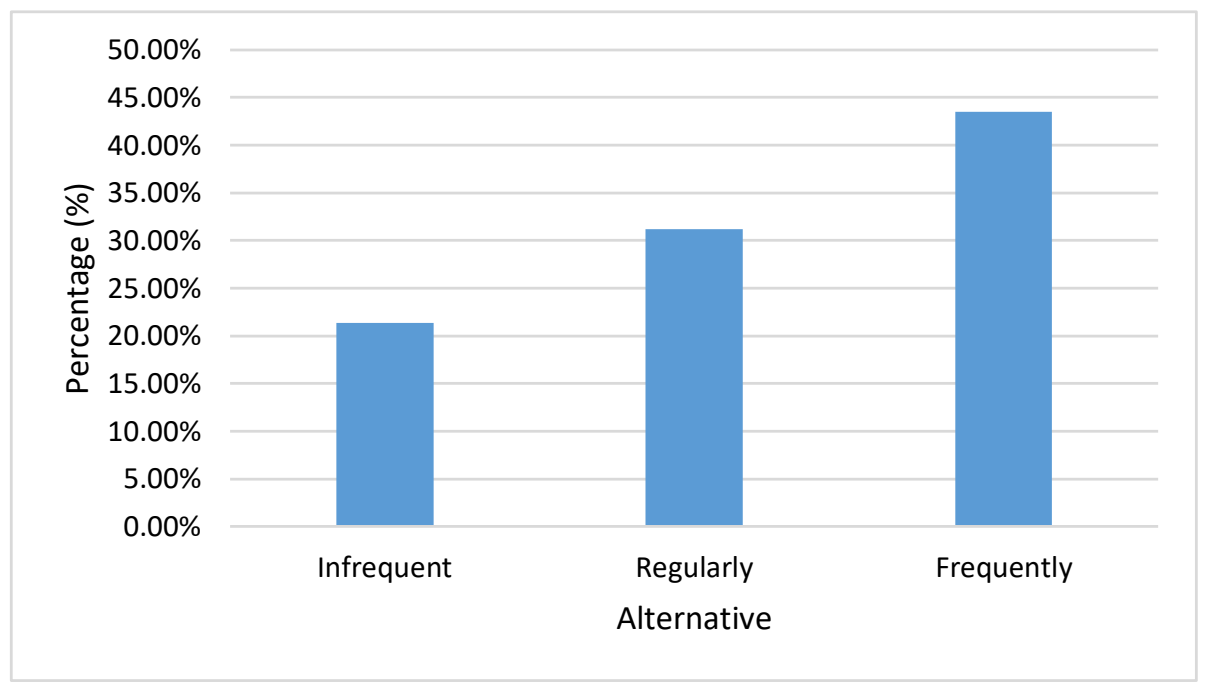

Figure 1. Frequency of Internet use

In relation to table $1,43.49 \%$ of the respondents expressed that they frequently use the Internet, $31.16 \%$ said that it regularly and $21.35 \%$ said that it was infrequent.

Table 2. Social network preference

\begin{tabular}{lcc}
\hline Alternatives & Frequency & $\begin{array}{c}\text { Percentage } \\
(\%)\end{array}$ \\
\hline Facebook & 97 & 25.26 \\
Twitter & 60 & 15.63 \\
Instagram & 55 & 14,32 \\
Youtube & 60 & 15.63 \\
Tik tok & 40 & 10.42 \\
Whatsapp & 39 & 10.14 \\
Others & 33 & 8.60 \\
\hline Total & 384 & 100.00 \\
\hline
\end{tabular}




\section{Journal of Global Management Sciences}

Vol. 4, $\mathrm{N}^{\circ}$ 1, 2021

Copyright @ 2021 , CINCADER.

ISSN 2663-0753

DOI: https://doi.org/10.32829/gmsj.v4i1.128
A publication of

\section{CINCADER}

Centre of Research and Training for

Regional Development Online at www.journals.cincader.org

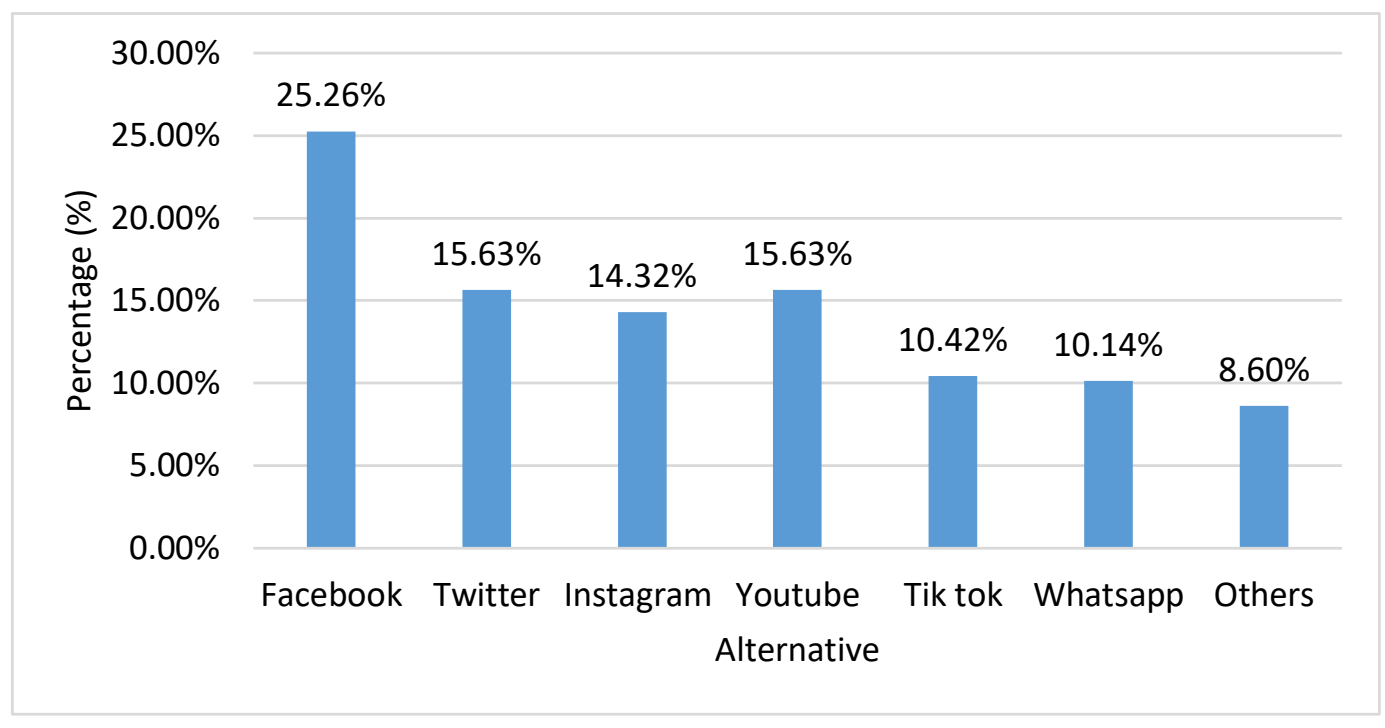

Figure 2. Social network preference

In relation to Table 2, $25.26 \%$ commented that Facebook is the social network they prefer, $15.63 \%$ said that it is Twitter, $15.63 \%$ said that YouTube, $14.32 \%$ answered that Instagram, $10.42 \%$ said that Tik Tok, 10.14 said WhatsApp, and $8.60 \%$ commented that others.

Table 3. The use of the social network of your preference is essential

\begin{tabular}{lcc}
\hline \multicolumn{1}{c}{ Alternatives } & Frequency & $\begin{array}{c}\text { Percentage } \\
(\%)\end{array}$ \\
\hline Yes & 208 & 54.17 \\
No & 106 & 27.60 \\
Sometimes & 70 & 18.23 \\
\hline Total & 384 & 100 \\
\hline
\end{tabular}

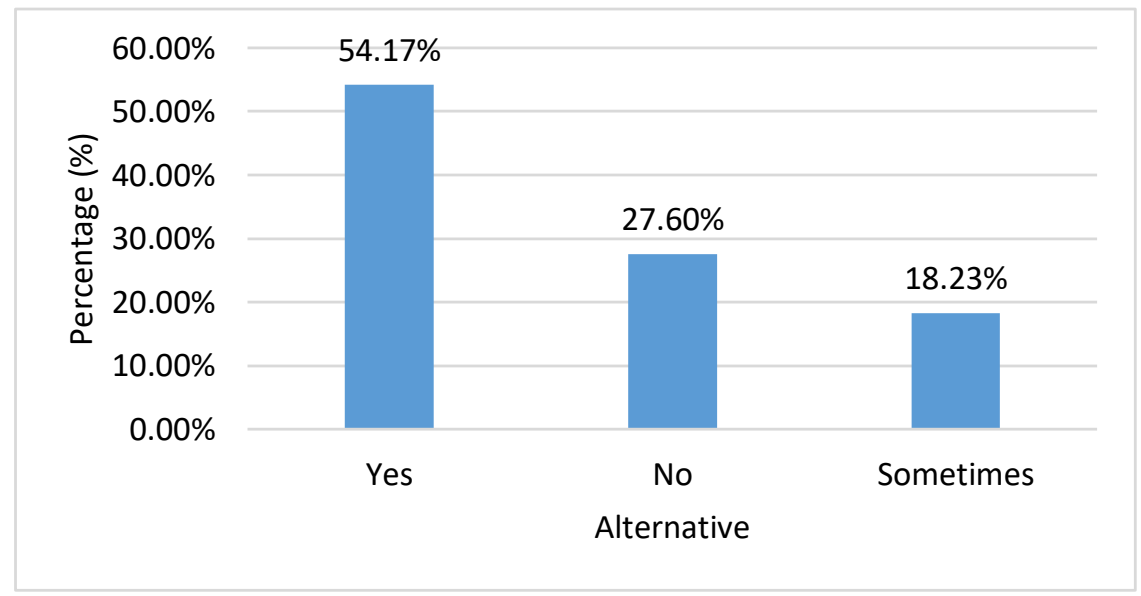

Figure 3. The use of the social network of your preference is essential 


\section{Journal of Global Management Sciences}

Vol. 4, $\mathrm{N}^{\circ} 1,2021$

Copyright (c) 2021, CINCADER.

ISSN 2663-0753

DOI: https://doi.org/10.32829/gmsj.v4i1.128
A publication of

\section{CINCADER}

Centre of Research and Training for

Regional Development

Online at www.journals.cincader.org

In relation to Table 3 , it is established that $54.17 \%$ said that yes, it is essential to use the social network of their preference, $27.60 \%$ said no and $18.23 \%$ said that sometimes.

Table 4. Number of hours of internet use per day

\begin{tabular}{lcc}
\hline \multicolumn{1}{c}{ Alternatives } & Frequency & $\begin{array}{c}\text { Percentage } \\
(\%)\end{array}$ \\
\hline Up to 1 hour & 30 & 7.81 \\
1 to 2 hours & 89 & 23.18 \\
2 to 3 hours & 90 & 23.44 \\
3 to 4 hours & 85 & 22.14 \\
4 to more than 5 hours & 90 & 23.84 \\
\hline Total & 384 & 100 \\
\hline
\end{tabular}

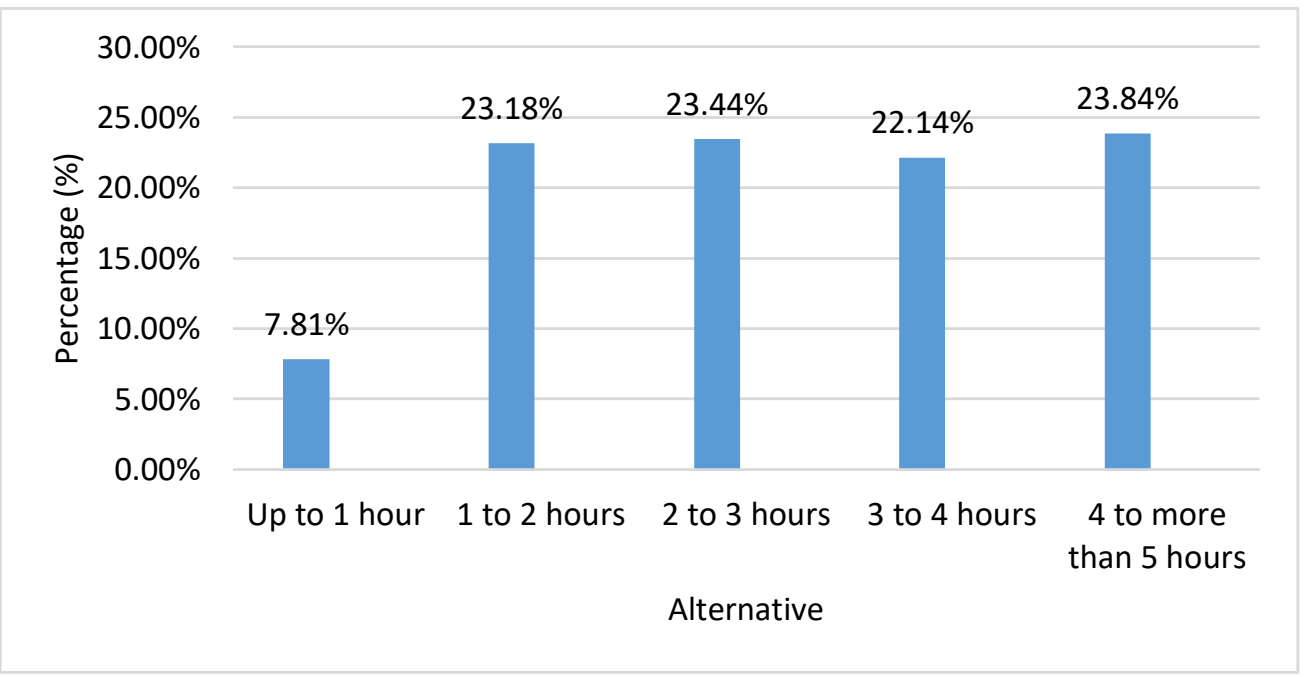

Figure 4. Number of hours of internet use per day

In relation to Table 4, it is established that $23.84 \%$ expressed that between 4 to more than 5 hours the number of hours of internet use per day, 23.44\% said that between 2 to 3 hours, $23.18 \%$ expressed that between 1 to 2 hours, 22.14 said that, from 3 to 4 hours, and $7.81 \%$ answered that 1 hour a day.

Tabla 5. Prioridad de conexión en alguna red social

\begin{tabular}{lcc}
\hline \multicolumn{1}{c}{ Alternatives } & Frequency & $\begin{array}{c}\text { Percentage } \\
(\%)\end{array}$ \\
\hline Yes & 134 & 34.90 \\
No & 121 & 31.51 \\
Sometimes & 129 & 33.59 \\
\hline Total & 384 & 100 \\
\hline
\end{tabular}




\section{Journal of Global Management Sciences}

Vol. 4, $\mathrm{N}^{\circ} 1,2021$

Copyright (C) 2021, CINCADER.

ISSN 2663-0753

DOI: https://doi.org/10.32829/gmsj.v4i1.128
A publication of

\section{CINCADER}

Centre of Research and Training for Regional Development Online at www.journals.cincader.org

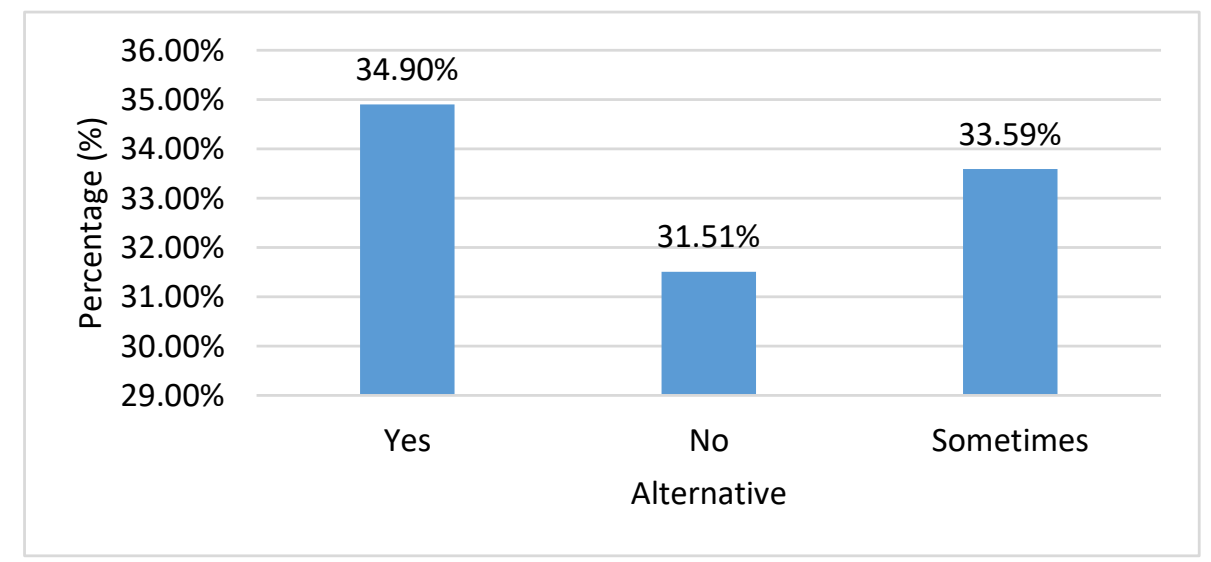

Figure 5. Prioridad de conexión en alguna red social

In relation to Table 5, 34.90\% said that yes, they set aside important activities to be connected to a social network, $33.59 \%$ said that, on some occasions, and $31.51 \%$ said no.

Table 6. Attraction of social networks

\begin{tabular}{lcc}
\hline Alternatives & Frequency & $\begin{array}{c}\text { Percentage } \\
(\%)\end{array}$ \\
\hline Chat with friends & 155 & 40.36 \\
Meet more people & 50 & 13.03 \\
Look at the states & 45 & 11.72 \\
Give my opinions and express myself freely & 49 & 12.76 \\
Visit virtual stores & 30 & 7.81 \\
Compare prices, offers, promotions & 32 & 8.33 \\
See fashion trends & 23 & 5.99 \\
\hline Total & 384 & 100.00 \\
\hline
\end{tabular}

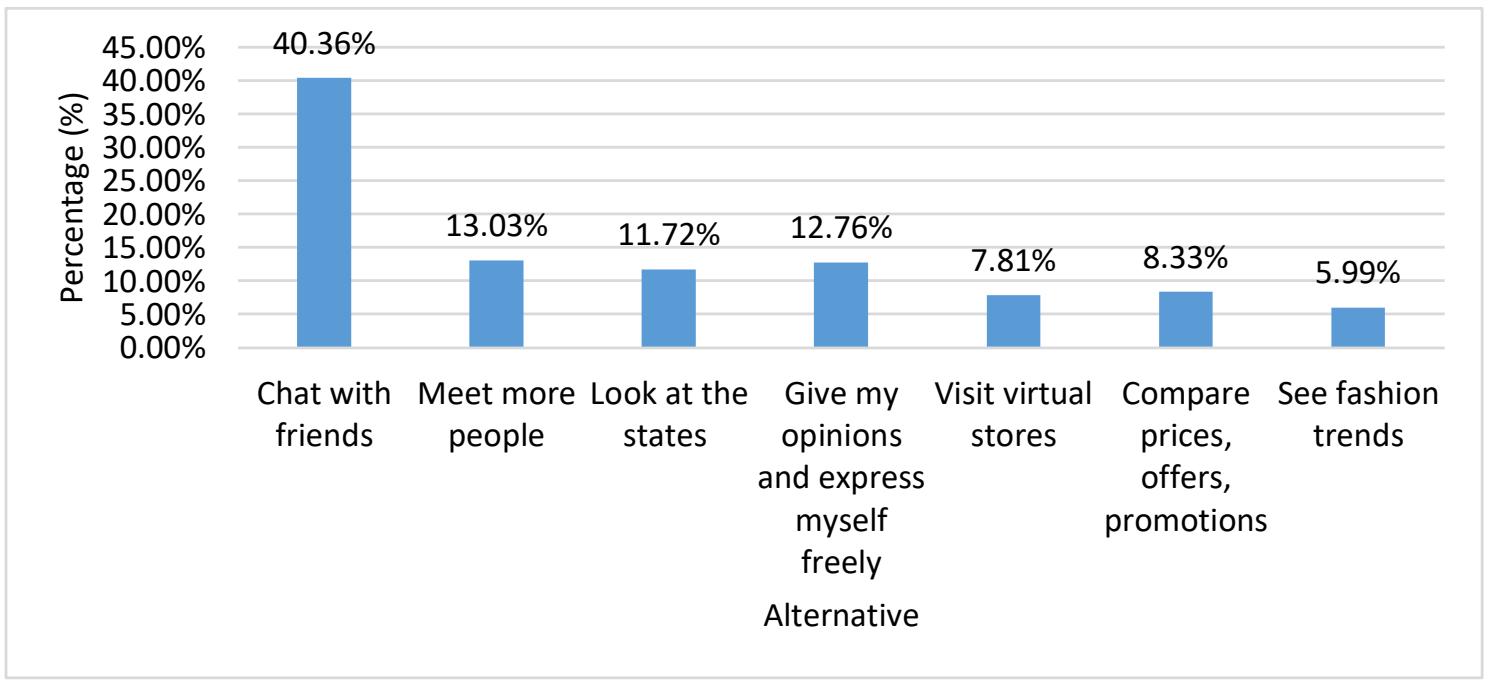

Figure 6. Attraction of social networks 


\section{Journal of Global Management Sciences}

Vol. 4, $\mathrm{N}^{\circ} 1,2021$

Copyright (C) 2021, CINCADER.

ISSN 2663-0753

DOI: https://doi.org/10.32829/gmsj.v4i1.128
A publication of

\section{CINCADER}

Centre of Research and Training for

Regional Development

Online at www.journals.cincader.org

In relation to Table $6,40.36 \%$ said that they are attracted to talking with their friends on social networks, $13.03 \%$ expressed to meet more people, $12.76 \%$ answered to give opinions and express themselves freely, $11.72 \%$ said to look at the states, $8.33 \%$ said they compare prices, $7.81 \%$ said they visit virtual stores, and $5.99 \%$ said they see fashion trends.

Table 7. Influence of the use of social networks in the purchase decision

\begin{tabular}{lcc}
\hline \multicolumn{1}{c}{ Alternatives } & Frequency & $\begin{array}{c}\text { Percentage } \\
(\%)\end{array}$ \\
\hline Yes & 142 & 37.98 \\
No & 100 & 26.4 \\
Sometimes & 142 & 37.98 \\
\hline Total & 384 & 100 \\
\hline
\end{tabular}

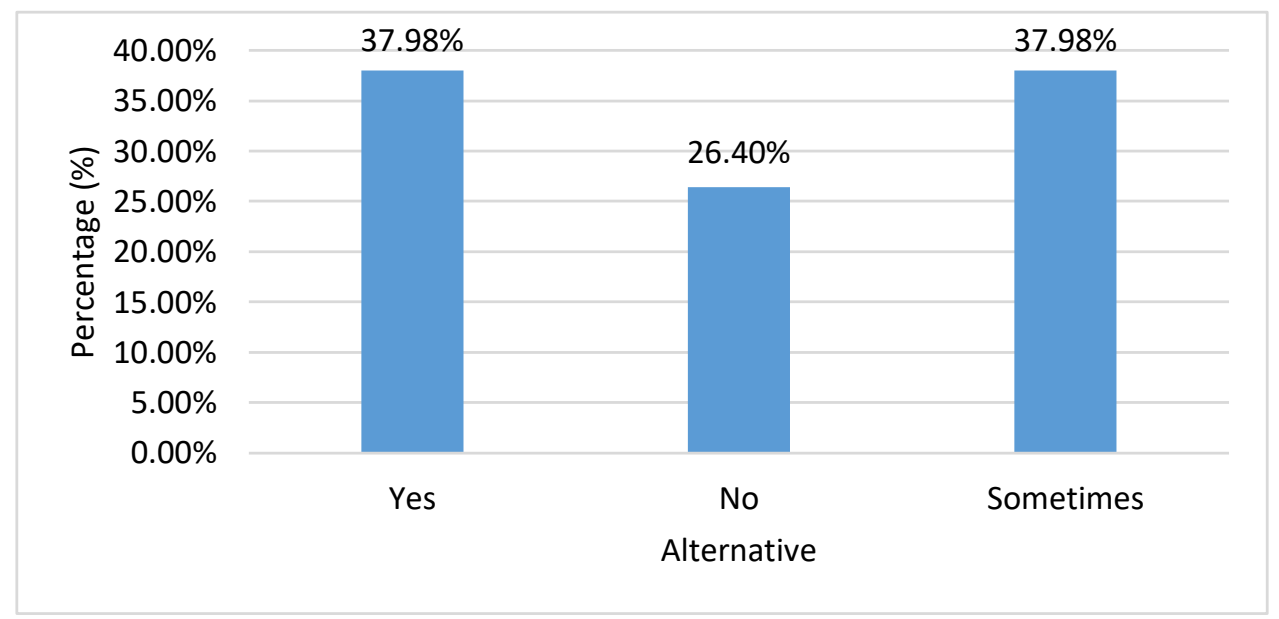

Figure 7. Influence of the use of social networks in the purchase decision

In relation to Table 7, 37.98\% expressed that yes, the use of social networks has influenced in some way in their purchase decision, $37.98 \%$ said that, on some occasions, in addition to $26.04 \%$ said that they had not.

Table 8. Access to social networks to make a purchase

\begin{tabular}{lcc}
\hline \multicolumn{1}{c}{ Alternatives } & Frequency & $\begin{array}{c}\text { Percentage } \\
(\%)\end{array}$ \\
\hline Yes & 120 & 31.25 \\
No & 114 & 29.69 \\
Sometimes & 150 & 39.06 \\
\hline Total & 384 & 100 \\
\hline
\end{tabular}




\section{Journal of Global Management Sciences}

Vol. 4, $\mathrm{N}^{\circ}$ 1, 2021

Copyright @ 2021, CINCADER.

ISSN 2663-0753

DOI: https://doi.org/10.32829/gmsj.v4i1.128
A publication of

\section{CINCADER}

Centre of Research and Training for

Regional Development

Online at www.journals.cincader.org

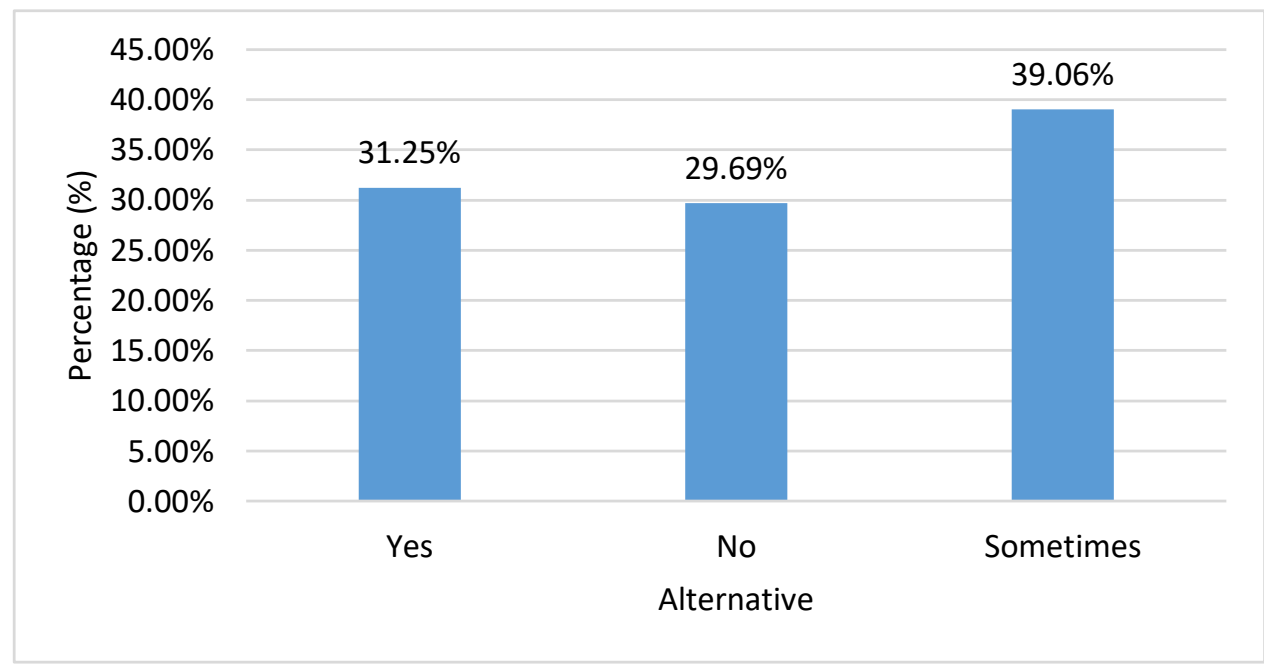

Figure 8. Access to social networks to make a purchase

In relation to Table 8, 39.06\% expressed that they sometimes access social networks to search when they want to make a purchase, $31.25 \%$ said yes, $29.69 \%$ said no.

Table 9. Viewing the information of the payment conditions when you are going to make a purchase

\begin{tabular}{lcc}
\hline \multicolumn{1}{c}{ Alternatives } & Frequency & $\begin{array}{c}\text { Percentage } \\
(\%)\end{array}$ \\
\hline Yes & 175 & 45.57 \\
No & 100 & 26.04 \\
Sometimes & 109 & 28.39 \\
\hline Total & 384 & 100 \\
\hline
\end{tabular}

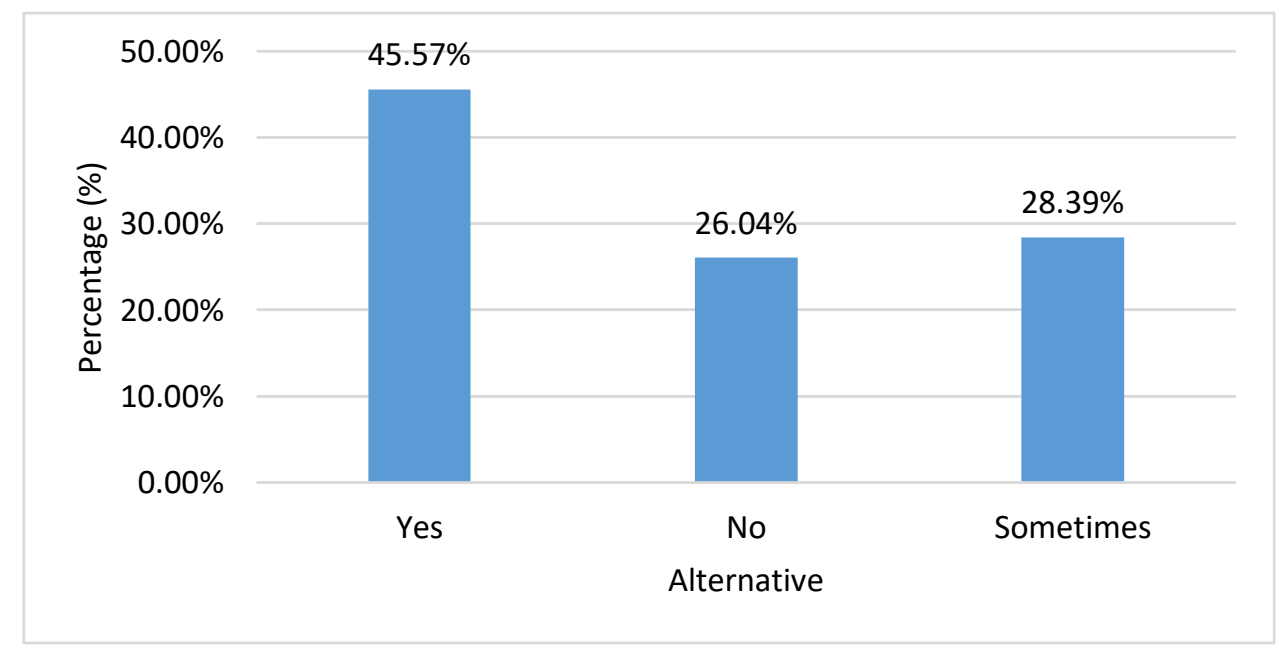

Figure 9. Viewing the information of the payment conditions when you are going to make a purchase 


\section{GMS \\ Journal of Global Management Sciences}

Vol. 4, $\mathrm{N}^{\circ}$ 1, 2021
Copyright @ 2021, CINCADER.

ISSN 2663-0753

DOI: https://doi.org/10.32829/gmsj.v4i1.128

In relation to Table $9,45.57 \%$ said yes, they consider information about the payment conditions when they are going to make a purchase, $28.39 \%$ said yes, $26.04 \%$ said no.

\section{Conclusions}

It was concluded that:

- Young people, due to their personal characteristics and the conflicts they are experiencing, require a personal and social world in which family, friends and loved ones share their lives. Social networks are constituted as an alternative to satisfy these needs, which is generating an increase in their addiction day by day because they are participants in the various alternatives that these environments offer.

- The technological alternatives offered by social networks today make it an opportunity for the training and development of young people, but it is necessary to recognize that they are also affecting the development of young people who access this virtual world. These, although they benefit the adolescent's training process, have a negative influence on physical and social activity, by spending many hours sitting, procrastinating the development of physical, academic and social activities, because they are connected on social networks.

- The research was oriented to the development of perception of the use of social networks in young people of the city of Ica. The study sought to know the habits and customs of those investigated, about the use of networks and the role played by the devices that produce, receive, process, store and transmit information without distance conditions, and in real time.

- It is concluded that; $43.49 \%$ stated that they frequently use the internet, $25.7 \%$ expressed that Facebook is the social network of their preference, another 54.17 stated that the use of the social network of their preference is essential, $34.9 \%$ said that important activities are be connected to a social network, in addition to a 40.36 established that what most attracts him is talking with friends.

\section{References}

Arredondo, P. 2007. Acceso y usos de internet en el occidente de México: el caso de Jalisco. Comunicación y Sociedad, (8), 11-33. Recuperado de http://bit.ly/2AzvAwH.

Blázquez, B. M., Gómez, R. D., Frontaura. F. I, Camacho O. A., Rodríguez, S. F., \& Toriz, C. H. 2018. Uso de Internet por los adolescentes en la búsqueda de información sanitaria. Atención Primaria, 50(9), 547-552. https://doi.org/10.1016/j.aprim.2017.06.005.

García, A. 2011. Una perspectiva sobre los riesgos y usos de Internet en la adolescencia. ICONO14 Revista Científica de Comunicación y Tecnologías Emergentes, 9(3), 410-425. https://doi.org/10.7195/ri14.v9i3.62.

Gómez, M., Roses, S., \& Farias, P. 2012. El uso académico de las redes sociales en universitarios. Comunicar, 19(38), 131-138. doi: https://doi/org/10.3916/C382011-03-04.

Namakforoosh, M. 2005. Metodología de la investigación. México: Limusa. 
Vol. 4, No 1, 2021

\section{Journal of Global \\ Management Sciences}

Copyright (C) 2021, CINCADER.

ISSN 2663-0753

DOI: https://doi.org/10.32829/gmsj.v4i1.128

Rodríguez, C., \& Sandoval, D. 2017. Estratificación digital; acceso y usos de las TIC en la población escolar chilena. REDIE, 19 20-34. https://doi.org/10.24320/redie.2017.19.1.902.

Zea, C. y Atuesta, R. 2008. Hacia una comunidad interactiva educativa. Medellín: Fondo Editorial Universidad Eafit.

Annexed.

Questionnaire on: "Use's perception of the social networks in young people at the Ica city, 2020".

1. How often do you use the Internet?

2. What social network do you prefer?

3. Is it essential to use the social network of your choice?

4. Number of hours of internet use per day?

5. Do you put aside important activities to stay connected to a social network?

6. What attracts you to social media?

7. Has the use of social networks influenced in any way your purchase decision?

8. Do you access social networks to search when you want to make a purchase?

9. Do you consider information about the payment conditions when you are going to make a purchase? 